\title{
Peran Perserikatan Buruh Dunia Terhadap Kekerasan Apartheid Zionis Israel Di Palestina
}

\author{
Ibnu Zulian \\ Program Studi Hubungan Internasional \\ Universitas Potensi Utama \\ Ibnuzulian45@gmail.com
}

\begin{abstract}
In this paper, the authors made a comparison of case studies between apartheid in Africa and Palestine. The success of the labor movement in Africa resolved the problem of apartheid on the basis of human rights and international law became a reference in analyzing and solving the problem of labor unrest in Palestine. The author has found that there are new forces in actions and protests called boycott movements, liberation and sanctions (BDS Movement), but with these 3 concepts, the movement cannot be viewed generally as having the right rational choice and global movement with the same objectives and common affairs.
\end{abstract}

Keywords: Apartheid, BDS Movement, Common Affairs.

\begin{abstract}
ABSTRAK
Di dalam paper ini, penulis membuat perbandingan studi kasus antara apartheid di Afrika dan Palestina. Keberhasilan pergerakan kaum buruh di Afrika menyelesaikan masalah apartheid atas dasar Hak Asasi Manusia dan Hukum Internasional menjadi referensi dalam menganalisis dan memecahkan masalah pergerkan buruh di Palestina. Penulis menemukan ada kekuatan baru dalam aksi dan protes kaum buruh yang disebut pergerakan boikot, pembebasan dan sangsi (BDS Movement), namun dengan 3 konsep pergerakan ini tidak bisa dipandang secara umum harus dengan pilihan rasional yang tepat dan pergerakan global dengan tujuan dan urusan yang sama (Common Affairs).
\end{abstract}

Kata Kunci: Apartheid, BDS Movement, Common Affairs

\section{LATAR BELAKANG}

Perjuangan kaum buruh tidak sekadar upah, selogan ini cocok untuk studi kasus jurnal ini, di mana persatuan buruh merupakan peran penting di dunia dalam menyikapi berbagai isu-isu dunia termasuk kasus apartheid di Palestina. Persatuan ini adalah awal bagaimana kaum buruh masuk dalam pergerakan sosial politik yang berorientasikan keadilan dan hak-hak asasi, bisa dikatakan pembelaan dan persatuan mereka atas rasa yang sama yaitu rasa ingin hidup yang layak, sejahtera dan damai. Ini merupakan salah satu 
tantangan sekaligus peranan kaum buruh di era globalisasi ini. Salah satu tantangan fonemena adalah imperialisme Zionis Israil terhadap Palestina yang menyinggung langsung terhadap kekerasan kaum buruh di sana.

Kekerasan kemanusiaan yang bersifat apartheid oleh rezim Zionis Israel ini sangat bertentangan dengan HAM (Human Right) dan Hukum Internasional (International Law) sehingga Al-Awda, The Plalestinian Right to Return Coalition, atau New York City Labor Againts the War (NYCLAW) mengirim surat terbuka kepada organisasi buruh dan para pekerja Amerika Serikat (AS). Surat yang ditandatangani oleh 31 organisasi buruh dan tokoh-tokoh nasional maupun internasional itu menyerukan agar organisasi buruh AS mendukung hak-hak bangsa Palestina, serta menyerukan dihentikannya bantuan ekonomi dan militer AS kepada Israel serta menghentikan semua investasi di Israel (Sulaeman, 2009: 157). Masih banyak lagi aksi-aksi serikat buruh dunia untuk memboikot Israel. Dalam aksi protes Internasional ini penulis melihat ada isu kemanusiaan yang tidak berperikemanusiaan dan berkeadilan sehingga timbul persamaan persepsi dalam pikiran dan pergerakan untuk membela kaum buruh di Palestina. Maka pertanyaan penulis adalah bagaimanakah peran kaum buruh dunia menghadapi apartheid Israel?

Kemudian Isu ini menjadi suatu pencapaian bersama pula dalam skala tata kelola global (global governance) dari lembaga Internasional non pemerintah. Becermin pada pergerakan buruh sedunia atas sistem apartheid di Afrika Selatan; di mana runtuhnya negara itu setelah mengalami pemboikotan dan tekanan organisasi buruh dari berbagai penjuru dunia.

\section{Pendekatan Teori}

\section{Global Governance}

Gagasan tentang pemahaman global goernance dari Rosenay dan Czempiel (1992) yang memaknai pemerintahan tanpa pemerintah (Governance without government). Gagasan ini sama dengan Finkelstein (1995) yang menjelasakan bahwa "Global gocernance is governing, without sovereign authority, relationship that trancend national frontiers. Global govenrnance is doing internationally what governments do at home”. Pengertian di atas menjelaskan situasi dan kondisi tentang kurangnya peran dari aktor pemerintah yaitu negara-bangsa dalam global governance. Selain itu, Thomas Weiis lebih dominan menekankan bahwa global governance adalah “... efort to bring more orderly 
and reliable responses to socail and political issues that go beyond capacities of states to adress individually". Isu global governance merupakan isu yang sangat cepat penyebarannya dan tidak mampu dibendung oleh negara-bangsa pada ruang diskursif saat ini.

Resiko global governance adalah dibutuhkan aksi-reaksi kemudian menjadi interaksi yaitu aktivitas banyak aktor. Kemudian pengertian yang cukup menarik oleh Commission on Global Governance (CGC), yaitu “... the sum of the many ways individuals and institutions, public and private, manage their common affairs. ... givernance has been viewed primarily as interngovernmental relationship, but it msut now be understood as also involving non-governmental organizations, citiziens' movements. Multinational corporations, and global capital market” (PPID Global Governance: 2010: 03). Pada definisi ini ada kata kunci "common affairs" yang menjadi dalil kuat akan institusi negara maupun organisasi internasional untuk bersama-sama mendiskusikan isu dan penyatuan persepsi secara bersama-sama. Di sisi lain, pihak yang berkepentingan juga mepunyai kepentingan yang sama.

Fenomena ini adalah gerakan yang membentuk sistem lalu merespon kegiatan secara bersama-sama (common affairs) dengan mengikut sertakan akar rumput dan komponen masyarakat internasional yaitu pemerintahan negara-bangsa maupun organisasi internasional dalam kapasitas yang global dan universal. Ini tercermin dalam peran serikat buruh dunia dalam solidaritas dan loyalitas, di mana setiap permasalahan yang berkaitan dengan isu-isu buruh sudah barang tentu menjadi perhatian mereka di seluruh dunia ini, tidak terkecuali di Palestina.

\section{Pergerakan Buruh dalam Rational Choice Teori}

\section{Teori Rational Choice}

Teori pilihan rasional pada dasarnya adalah tindakan untuk mengoptimalisasikan pilihanpilhan yang ada dalam kondisi tertentu. Di negara-negara Eropa sangat dominan dipengaruhi oleh teori ini, namun gerakan ini mengalamai transformasi. Dahulu gerakan buruh terlibat dalam konflik kelas, sedangkan gerakan kotemporer seperti anti perang, lingkungan, hak-hak sipil, feminis, dan lain-lain, malah terlibat dalam konflik sosial dan politik. Aktivis gerakan kotemporer ini merupakan bentuk politik post-materialisme dan dibuat dalam bentuk identitas baru, terutama yang dari kelas menengah. Gerakan Ini berfokus pada nilai dampak dari gerakan sosial terhadap masyarakat, dan faktor-faktor 
yang menyebabkan dampak tersebut dapat beresonansi pada individu, lembaga, budaya, atau sistem politik (Amenta, et al, 2010: 287-307).

Individu adalah aktor rasional yang strategis mempertimbangkan biaya dan manfaat dari program alternatif tindakan dan memilih tindakan yang paling mungkin untuk memaksimalkan utilitas mereka. Masalah penelitian utama dari perspektif ini adalah masalah tindakan kolektif, atau mengapa orang rasional akan memilih untuk bergabung dalam aksi kolektif jika mereka mendapatkan keuntungan dari akuisisi bahkan jika mereka tidak berpartisipasi. Dalam karya Mancur Olson, Mark Lichbach, dan Dennis Chong dalam Protes Politik dan Gerakan Sosial, menggabungkan sejumlah konsep budaya dalam versi teori pilihan rasional, serta menunjukkan bahwa beberapa pendekatan lain diam-diam mengandalkan asumsi pilihan rasional tanpa mengakuinya (Dieter, 2009: 29). Klaim aktivis tertentu membuat atas nama gerakan sosial mereka 'beresonansi' dengan penonton termasuk media, sekutu elit, simpatisan, dan calon potensial. Begitu juga dengan Frame, berhasil memanfaatkan pemahaman bersama budaya misalnya hak dan moralitas. Perspektif ini berakar kuat dalam ontologi sosial konstruktivis.

Imajinasi gerakan sosial selama ini dibentuk oleh berbagai prinsip ideal sementara dalam praktek perkembangannya dibatasi oleh pergulatan kuasa yang sangat konkret. Jarak di antara keduanya membuat narasi gerakan sosial melulu soal kekalahan/kegagalan dan kekurangan. Diperlukan perangkat konseptual berbeda untuk memahami tempat gerakan sosial dalam pergulatan kuasa yang sangat konkret. Pembedaan civil society dan political society adalah langkah awal yang berguna (Farid, 2014:01). Selama dekade terakhir, teori politik sebagian berpeluang disesuaikan dengan perspektif framing. Hal ini disebut teori politik dari gerakan sosial.

\section{PEMBAHASAN}

\section{Pengertian Apartheid}

Asal muasal kata Apartheid terbagi menjadi dua yaitu apart dan heid artinya memisah dan hukum atau sistem. Apartheid merupakan gerakan politik dengan sistem anti persatuan terhadap pembedaan ras, agama, kepercayaan, kotomi kelas sosia yaitu komunitas mayoritas akan mendominasi komunitas minoritas. Gerakan politik dilakukan oleh aktor pemerintah demi melindungi hak istimewa suatu ras dan bangsa yang mungkin saja tidak tertuang dalam nilai-nilai konstitusi. Sistem politik ini mulai diberlakukan pada abad ke-20 hinggga tahun 1990-an dan dilakukan oleh pemerintah kulit putih pada ras dan 
kesukukan bangsa di Afrika Selatan (https://pengertianmenurutparaahli.org/pengertianapartheid-dan-contohnya/ Diakses pada 08 September 2018). Di bawah ini merupakan tinjauan dan perbandingan tentang Apartheid Afrika dan Palestina.

\section{Afrika Apartheid}

Apartheid adalah sistem pemisahan ras legal yang diterapkan di Republik Afrika Selatan dari tahun 1948 sampai 1993. Apartheid berasal dari kata bahasa Afrika yang berarti terpisah. Di Afrika Selatan, ras dibedakan menjadi empat golongan yaitu kulit putih yang notabene keturunana Eropa, suku bangsa bantu (salah satu suku banga di Afrika Selatan), orang Asia (Pakistan \& India) dan orang campuran atau kulit berwarna yang merupakan keturuanan Melayu Cape. Politik apartheid menganggap bahwa kulit hitam itu adalah orang hina yang patut untuk diasingkan dan disingkirkan, berbeda dnegan halnya kulit putih yang patut untuk dihormati dan berhak menjadi pemimpin. Gerakan Politik ini salah satu bentuk pelanggaran Hak Asasi Manusia dan dianggap sebagai diskriminasi rasial yang dilakukan oleh Bangsa Barat. Politik ini dapat kecaman dari Perserikan BangsaBangsa (PBB) dan menganggap ini salah satu politik terkutuk yang pernah ada (Op Cit.) Bibit apartheid sebenarnya telah tumbuh jauh sebelum tahun 1948 dan terus menghantui Afrika Selatan kemudian dihapuskan. Di bawah sistem ini, diskriminasi terjadi terhadap orang kulit hitam dilegalkan oleh hukum, denagn sistem tersebut orang kulit putih memiliki akses lebih mendapatkan perumahan, pekerjaan, pendidikan, dan kekuasaan politik. Meskipun Afrika Selatan mendapat kritik keras, apartheid mulai dihapuskan pada tahun 1991 (Doni, 2013: Par 05).

Sistem apartheid ini punah saat Nelson Mandela terpilih sebagai presiden kulit hitam pertama Afrika Selatan pada tahun 1994. Undang-undang pertama yang mengatur sistem apartheid adalah Group Areas Act of 1950 yang memisahkan ruang hidup antar warga negara. Orang kulit putih hidup di perkotaan dan kulit berwarna tinggal di pedesaan atau pinggir kota. Pada masa itu, orang kulit putih dan non-kulit putih melakukan pekerjaan yang berbeda, tinggal di daerah berbeda, serta memiliki gaji, akses pendidikan, dan akses kesehatan yang berbeda pula. Ketika orang kulit hitam dipaksa keluar dari perkotaan, daerah tempat tinggal mereka disebut sebagai Bantustan atau tanah air Afrika (Tan, 2018: Par. 09).

Warga kulit hitam tidak boleh ambil bagian pada kegiatan pemerintah dan dipaksa mematuhi aturan jika ingin bepergian ke luar kampung halaman. Lalu muncul tokoh yang bernama Nelson Mandela. Dia adalah anggota Kongres Nasional Afrika (African National Congress atau ANC), sebuah kelompok yang berjuang untuk menghapuskan apartheid. 
Mandela bergabung dengan ANC tepat sebelum PD II dan mendorong organisasi tersebut menjadi gerakan nasional. ANC menggunakan perlawanan tanpa kekerasan, pemogokan, dan pembangkangan sipil massal untuk memperjuangkan persamaan hak. Pada tahun 1952, Mandela diadili karena berpartisipasi dalam Campaign of Just Defiance dan dijatuhi hukuman percobaan. (https://www.amazine.co/25039/apa-itu-apartheid-fakta-sejarahinformasi-lainnya/. Akses pada 04 September 2018).

Selanjutnya, Pada Tahu 1950, Mandela menghabiskan waktu menjadi pengacara untuk membantu warga kulit hitam. Pada tahun 1960, ANC resmi dilarang. Mandela kemudian menjadi salah satu pendiri Umkhonto we Sizwe, sebuah organisasi hak-hak sipil kekerasan, meskipun keanggotaannya tidak berlangsung lama. Pada tahun 1962, setelah berkeliling ke luar negeri untuk berbicara tentang situasi di Afrika Selatan dan menerima pelatihan militer, Mandela dipenjara seumur hidup dan tidak dibebaskan sampai tahun 1990. Saat apartheid mulai dihapuskan, ANC kemudian direformasi pada tahun 1991 untuk kemudian memilih Mandela sebagai presiden organisasi tersebut. Perjuangan yang dilakukan rakyat Afrika dan Nelson Mandela memakan waktu yang cukup lama, namun waktu yang lama itu akhirnya terbalaskan ketika pemerintah kulit putih dibawah pimpinan Frederik Willem de Klersk memberikan angin segar petanda kebebasan bagu warga kulit hitam. Pada tanggal 21 Februari 1991 Frederik Willem de Klerk mengumumkan penghapusan ketentuan dan eksitensi dari politik apartheid (Setyawan, 2015: Par 03). Pengumuman itu juga diikuti dengan penghapusan UU kekuasaan apartheid yang berisi:

a. Land Act, UU yang melarang rakyat kulit hitam untuk mepunyai rumah di luar daerah yang telah ditentukan.

b. Group Areas Act, UU yang mengatur adanya pemisahan tempat tinggal antara kulit hitam dan kulit putih.

c. Population Registration Act, UU yang berisi kewajiban bagi rakyat kulit hitam untukmendaftarkan diri berdasarkan kelompok dan sukunya masing-masing.

d. Bantu Self Government Act, dibangun ghetto bagi kaum kulit hitam. System ini ditujukan agar kaum kulit hitam kehilangan hak politiknya dalam politik Afrika Selatan. Kaum kulit hitam hanya boleh mempelajari tentang kebudayaan masing-masing, harus memiliki surat jalan jika ingin keluar dari wilayahnya, dan dilarang melakukan perkawinan antar ras.

Pada pemilu tahun 1994, Nelson Mandela terpilih menjadi presiden Afrika Selatan dan menjabat hingga tahun 1999. Sebelumnya, Mandela juga memenangkan Hadiah Nobel 
Perdamaian pada tahun 1993 sebagai pengakuan atas usahanya mengakhiri apartheid di Afrika Selatan.

\section{Israel Apartheid}

Pada bulan Februari 2002, Zionis Israel mengebom kantor Federasi Organisasi Buruh Palestina di Nablus. Misi Israel ini meneruskan agenda organisasi AFL-CIO (Sulaeman, 2009: 154). Demi membangun perumahan dan pusat-pusat kebudayaan Israel di daerah Nablus, kutukan dan dukungan dari penjuru dunia berdatangan seperti dari serikat buruh terbesar di Inggris yaitu UNITE, serikat Inggris ini mengutuk kejahatan Zionis Israel yang dilakukan di wilayah Palestina. Kemudian dukungan UNITE ini juga diperkuat oleh pernyataaan Middle East Monitor (MEMO). Menurut MEMO; Unite juga mengutuk pelanggaran Zionis Israel terhadap hukum internasional seperti terus berlanjutnya pembangunan permukiman ilegal, kejahatan penganiayaan terhadap rakyat Palestina, serta penahanan dan penyiksaan terhadap anak-anak Palestina. Tidak hanya itu, kekerasan manusia yang bersifat apartheid ini dikecam oleh berbagai aliansi buruh negara di dunia, seperti Amerika Serikat (AS), Afrika Selatan, Norwegia, Kanada, dan lain-lain (Setiawan, 2014: 04).

Berselang beberapa tahun, tepat pada bulan Juni 20017, pengepungan dan penyerangan dilakukan oleh Zionis Israel terhadap wilayah Gaza, Penyerangan dengan cara pengeboman bertubi-tubi dilakukan juga pada bulan Desember 2008 dan Januari 2009. Kejadian ini menjadi momentum peningkatan dalam mendukung kampanye untuk boikot, Divestasi dan Sanksi (BDS). Di Swedia Serikat buruh dockworkers menyatakan telah memboikot barang-barag hasil produksi dari Israel, serta kapal Israel yang datang memasuki wilayah negara tersebut. Mereka juga telah berkomunikasi dan berkoordinasi dengan serikat lain untuk membuat pergerakan serupa, dan telah menyuarakan blokade secara kolektif dan berkesinambungan terhadap barang-barang produksi dari Israel, kegiatan dilakukan demi hak-hak Palestina dapat diakui, wacana dan isu ini menajdi tren pada waktu itu. Beberapa hari kemudian Dockers Norwegia bergabung degan misi yang sama yaitu boikot. Pergerakan ini merupakan gambaran akan solidaritas buruh terhadap orang-orang Palestina. Gerakan ini dibuat bukan tanapa kontroversial karena pada saat itu parlemen Swedia bersikap oposisi ringan, yaitu hanya sekedar protes, berdebat atas pembajakan Kapal dan barang-barang produksi dari Israel.

Mengisolasi Negara Israel dengan tindakan memaksa pemerintah Swedia menghentikan dukungan penindasan Zionis Israel terhadap Palestina, Penguatan 
penolakan ini bukan tanpa kausal, karena salah satu senjata terkuat yang digunakan Zionis Israel untuk mengakhiri pengepungan Gaza merupakan tindakan yang paling represif, seperti kebijakan yang di dalamnya ada rasa balas dendam atas perusakan pemukiman, dan pembatasan perbatasan kebebasan gerakan pejuang Palestina. Mencuatnya isu negara Israel bersamaan dengan apartheid etnis Arab diusir dari tanah kelahiran mereka sehingga sebagian besar etnis Yahudi Israel diberdayakan di Palestina, namun pada awal merupakan dominasi Arab yang berada di sana. Strategi Israel mampu kuat kembali sebagai penduduk mayoritas Yahudi adalah melalui imigrasi kaum Yahudi dengan proyek dan gerakan yang besar, dan didukung juga dengan aturan institusi yang tidak adil terhadap kaum selain Yahudi dan melarang warga Palestina kembali ke tanah kelahiran mereka. Berdasarkan kejadian ini, dapat dikatakan ini merupaka ideologi yang bersifat rasis dari gerakan Zionis yang ingin mengapai cita-cita menjadi negara istimewa atas dominasi kaum Yahudi dan siap menendang balik kaum Arab Palestina (Hatuel, 2015: Par. 03). Koloniaslisme Zionis terhadap kaum Arab Palestina semakin kuat yaitu melalui hak-hak asasi yang bersifat nasionalis, Maka intervensi internasional terhadap gerakan Zionis Israel bukan sekedar kata-kata, tetapi juga tindakan nyata yaitu menunjukkan pengaruh positif bahwa ideologi Zionis sangat penting dipahami karena kejadian ini sama di Afrika Selatan pada tahun 1980-an, di mana serikat pekerja kulit hitam yang menyerukan sanksi internasional terhadap pelaku apartheid dan penindasan.

Berkenaan dengan situasi di Israel sendiri, kritik klaim mengklaim bahwa Israel tidak dapat disebut negara apartheid karena tidak seperti Afrika Selatan, yang diabadikan kebijakan segregasi rasial dalam hukum, hukum Israel adalah sama untuk warga Yahudi dan warga negara Israel lainnya, dengan tidak ada perbedaan eksplisit antara ras, keyakinan atau seks. Mitchel G, Bard (2008) "Israel Is Not An Apartheid State", tetapi bangsa yang lain percaya bahwa hukum dan peraturan tertentu secara eksplisit atau implisit melakukan diskriminasi atas dasar atau keyakinan atau ras yang pada. Dasarnya adalah mengistimewakan warga Yahudi dan merugikan non-Yahudi, dan khususnya Arab dan warga negara lainnya. Ini termasuk Hukum Pengembalian, hukum yang membuat wajib militer wajib untuk agama tertentu saja, Larangan Penyatuan Keluarga, dan banyak undang-undang tentang keamanan, tanah dan perencanaan, kewarganegaraan, perwakilan politik di Knesset, pendidikan dan budaya. 


\section{Peran Perserikatan Buruh Dunia}

Dalam melihat upaya-upaya masyarakat sipil anti-Israel dari bawah ke atas di arena PBB, 21 persen dokumen yang berkaitan dengan Israel dan apartheid diajukan ke forum PBB oleh LSM pro-Palestina dibandingkan dengan 1 persen dokumen selama 15 tahun yang diajukan oleh LSM pro-Israel (Hatuel \& Radoshitzky, Vol 8, 2015: 112). Temuan ini dengan jelas mengilustrasikan sentralitas yang dimainkan oleh para aktivis LSM dan masyarakat sipil dalam memelihara perhatian negatif yang diarahkan pada Israel dan mendorong minat perlawanan terhadap tindakannya terhadap warga Palestina.

Tabel 1. Dokumen PBB tentang Israel dan Apartheid tahun 2000-2014.

\begin{tabular}{|l|c|c|c|}
\hline & $\mathbf{2 0 0 0 - 2 0 0 9}$ & $\mathbf{2 0 1 0 - 2 0 1 4}$ & Hasil \\
\hline $\begin{array}{l}\text { Jumlah dokumen } \\
\text { yang mengacu pada }\end{array}$ & $53(52 \%)$ & $31(62 \%)$ & $84(56 \%)$ \\
$\begin{array}{l}\text { Israel sebagai negara } \\
\text { apartheid }\end{array}$ & $18(18 \%)$ & $13(26 \%)$ & $31(21 \%)$ \\
\hline $\begin{array}{l}\text { Jumlah dokumen } \\
\text { yang diserahkan ke } \\
\text { PBB atas nama } \\
\text { organisasi } \\
\text { masyarakat sipil } \\
\text { Palestina }\end{array}$ & & & \\
\hline \multicolumn{1}{|c|}{ Total } & $\mathbf{1 0 1}$ & $\mathbf{5 0}$ & $\mathbf{1 5 1}$ \\
\hline
\end{tabular}

Sumber: Michal Hatuel \& Radoshitzky. Israel and Apartheid in

International Discourse. Strategic Assessment. Volume 18 No. 3 | October 2015.

Dalam memecah analisis menjadi dua periode waktu yaitu, 2000-2009, dan 2010-2014. Muncul dua kecenderungan (tabel 1): (a) peningkatan (dari 52 persen semua item dalam periode pertama menjadi 62 persen dari semua item pada periode kedua) dokumen yang berkaitan dengan Israel sebagai negara apartheid; dan (b) peningkatan (18 persen dari semua item dalam periode pertama hingga 26 persen dari semua item dalam periode Kedua) dalam proporsi dokumen yang berkaitan dengan Israel dan apartheid yang diserahkan kepada PBB atas nama warga sipil Palestina organisasi masyarakat.

Boycott, Divestment and Sanctions Movement (BDS Movement) merupakan kampanye global, yaitu berusaha untuk meningkatkan tekanan ekonomi-politik di Israel untuk menjalan tujuan lain dari gerakan pendudukan kaum Yahudi Israel dan strategi kolonisasi di Palestina. Hak Asasi penuh untuk semua warga Arab di Palestina, dan menghormati hak kembali pengungsi Palestina. Kampanye ini dimulai pada tahun 2005 oleh 171 organisasi dari luar pemerintah Palestina. Mendukung perjuangan Palestina untuk memboikot, divestasi dan sanksi internasional terhadap Israel. Mengutip batang tubuh 
resolusi PBB dan secara khusus menggemakan kampanye anti-apartheid terhadap kekuasaan minoritas kulit putih di Afrika Selatan, kampanye BDS Movement menyerukan berbagai bentuk boikot terhadap negara mana saja yang mempunyai tujuan dan misi tertentu tentang apartheid dan memenuhi kewajiban Hak Asasi Manusia di setiap warga negara yang merdeka di bawah hukum internasional.

$B D S$ Movements juga memiliki kontroversial tentang batasan, efektivitas dan moralitas dari gerakan BDS. Kritikus berpendapat bahwa gerakan BDS mempromosikan delegitimisasi Israel yang semakin semena--mena. Pendukung BDS berpendapat gerakan kritik mereka merupakan gerakan sama dengan gerakan boikot sebelumnya yaitu di Afrika Selatan, perbedaan pandanagn tentang pergerkan bersifat kritik pasti dapat penolakan dengan alasan perbedaan rezim pada setiap aspek kepentingan baik sosial, politik dan ekonomi. Efektivitas gerakan telah dipertanyakan. Laporan dari dalam dan luar Israel telah mengindikasikan bahwa gerakan ini telah memiliki dampak yang sangat kecil pada ekonomi Israel, dan tidak akan berhasil di masa mendatang.

Pada hari Senin 1 Maret tahun 2005, Masyarakat di 40 kota di dunia dari Montreal di Kanada hingga Cape Town di Afrika Selatan dan berbagai tempat lainnya di berbagai belahan dunia melakukan aksi untuk memperingati "minggu Apartheid Israel" yang ke 6. Aksi protes ini dilakukan sebagai bentuk penentangan terhadap penindasan yang dilakukan zionis Israel terhadap rakyat Palestina. Acara ini dilakukan sebagai tindak lanjut atas kesuksesan dari gerakan boikot, pemutusan hubungan dagang dan sangsi di level global, demikian tulis perancang kegiatan ini dalam situs mereka. Event global ini menampilkan pidato dan aksi unjuk rasa mengenai nasib buruk bangsa Palestina dan kekejaman zionis Israel. Beberapa isu yang turut diusung dalam acara ini seperti adanya hari Nakba, pemenjaraan aktivis Palestina, diskriminasi buruh dan pembangunan tembok pemisah oleh Israel di Tepi Barat (http://www.muslimdaily.net/berita/internasional/dunia-peringatiminggu-apartheid-israel.html Diakses Pada 04 September 2018).

Israeli Apartheid Week (IAW) mengatakan bahwa aksi ini sesuai dengan mementum 1 tahun perang di Gaza tahun lalu. Aksi IAW pertama diselenggarakan oleh mahasiswa Arab di Universitas Toronto tahun 2005 sebagai wujud solidaritas kepada rakyat Palestina dan negara lain yang ditekan. Tahun 2006 IAW berkembang hingga Montreal dan Oxford, dan bertambah 5 lokasi lagi tahun 2007 termasuk New York. Tahun 2008, 19 kota baru ikut berpartisipasi dan di tahun 2009 aksi ini dilakukan di 27 kota. Dan tahun 2010 ini dilakukan di 40 kota sebagai bagian kampanye kepedulian terhadap Palestina (Op.Cit.). 
D’Orazio, koordinator media dari Mahasiswa Penentang Apartheid Israel di Universitas Carleton mengatakan tujuan event ini juga untuk memboikot Israel. Pihaknya berharap agar Universitas tempatnya bernaung mau memutus hubungan kerjasama dengan perusahaan Israel. Tujuannya adalah membuat Universitas Carleton menjadi universitas pertama di Kanada yang secara penuh memutus hubungan kerjasama dengan perusahaan Israel. Pada bulan Februari 2009, Hampshire College menjadi institut pertama di Amerika yang memutuskan kerjasama dengan perusahaan yang terlibat dalam pendudukan Israel di Palestina (Roji, 2010: Par 07). Patut ditunggu bagaimana tindakan negara-negara Muslim di dunia dan OKI dalam bersikap terhadap Israel, apakah mereka bisa berbuat banyak melihat penderitaan rakyat Palestina sebagai sesama saudara Muslim.

\section{Tinjauan HAM \& Hukum Internasional}

Pada tahun 1973, Konvensi Internasional tentang Penindasan dan Penghukuman Kejahatan Apartheid (ICSPCA) diadopsi oleh Majelis Umum Perserikatan Bangsa-Bangsa. The ICSPCA defines the crime of apartheid as "inhuman acts committed for the purpose of establishing and maintaining domination by one racial group ... over another racial group ... and systematically oppressing them". Kejahatan apartheid sebagai tindakan tidak manusiawi yang dilakukan untuk tujuan menetapkan dan mempertahankan dominasi oleh satu kelompok ras atas kelompok ras lain dan secara sistematis menindas mereka (United Nation, http://www.unhcr.org/refworld/pdfid/3ae6b3c00.pdf. Diakses pada 08 September 2018).

Pada tahun 2002 kejahatan apartheid didefinisikan lebih lanjut oleh Pasal 7 Statuta Roma dari Pengadilan Pidana Internasional karena mencakup tindakan tidak manusiawi seperti penyiksaan, pembunuhan, pemindahan paksa, pemenjaraan, atau penganiayaan kelompok yang dapat diidentifikasi pada politik, ras, nasional, etnis. , budaya, agama, atau alasan lain, "berkomitmen dalam konteks rezim yang dilembagakan dari penindasan dan dominasi sistematis oleh satu kelompok ras atas kelompok atau kelompok ras apa pun dan berkomitmen dengan niat mempertahankan rezim itu" (United Nation, http://legal.un.org/icc/statute/english/rome_statute(e).pdf. Diakses pada 08 September 2018). Penulis politik Ronald Bruce St John (2007: Par 16) berpendapat bahwa dalam hal kebijakan ICSPCA Israel di Tepi Barat tidak dapat secara teknis didefinisikan sebagai apartheid, karena ia tidak memiliki komponen rasial. Kemudian Ronald menyatakan bahwa dengan diperkenalkannya Statuta Roma tentang Pengadilan Pidana Internasional tahun 2002 penekanan ini beralih ke kelompok nasional, etnis atau budaya yang dapat 
diidentifikasi, sebagai lawan dari kelompok ras dalam hal ini kebijakan Israel di Tepi Barat jelas merupakan bentuk apartheid dengan efek pada rakyat Palestina sama seperti apartheid terhadap penduduk non-kulit putih di Afrika Selatan.

Laporan The Human Sciences Research Council (HSRC) tahun 2009 (http://www.hsrc.ac.za/Document-3227.phtml. Diakses pada 08 September 2018) menyatakan bahwa di Wilayah Pendudukan Palestina, identitas Yahudi dan Palestina adalah Dibangun secara sosial sebagai kelompok yang dibedakan berdasarkan leluhur atau keturunan serta kebangsaan, etnis, dan agama". Atas dasar ini, studi ini menyimpulkan bahwa orang Yahudi Israel dan Arab Palestina dapat dianggap kelompok rasial untuk tujuan definisi apartheid dalam hukum internasional.

Selain itu, hukum kemanusiaan yang merupakan dasar dari peperangan, menunjuki wilayah yang diduduki sebagai daerah militer tertutup dan karena itu orang yang ingin meninggalkan daerah itu memerlukan izin karena masalah berkepanjangan tentang pendudukan di masa lalu norma itu untuk mengakomodasi gerakan Palestina semaksimum mungkin (Cohen, 1980: 648). Oleh karena itu, selama periode yang relatif tenang, izin untuk meninggalkan diberikan dengan mudah. Meninggalkan Pembatasan dan memasuki wilayah dimulai sebagai serangan terhadap warga Israel di wilayah Israel menjadi lebih sering. Pembatasan ini sesuai dengan hukum kemanusiaan dan bahkan dengan hukum hak asasi manusia yang memungkinkan pembatasan kebebasan bergerak untuk alasan keamanan (Sassoli, 1999: 154-155).

Para peneliti dan penulis dunia banyak mengklaim bahwa Israel melanggar hak-hak Palestina dengan tidak membiarkan warga Palestina untuk masuk dan bekerja di Israel, ini adalah kesalahan (Zilbershats, 2013: 920). Wilayah hijau bukan bagian dari Israel, dan karena itu memasuki wilayah Israel setara dengan memasuki warga negara asing ke Israel. Ini adalah aturan dasar hukum internasional bahwa negara berdaulat, dalam hal ini Israel bisa memutuskan siapa yang akan masuk perbatasannya. Kewajiban Seorang negara untuk memungkinkan masuk ke wilayahnya terbatas pada warganya sendiri dan residen.

Dengan demikian, tidak ada kewajiban pada Israel untuk memungkinkan warga dari wilayah lain untuk masuk Israel atau tugas apapun itu untuk menyediakan mereka dengan pekerjaan dalam perbatasannya. Meskipun ruang lingkup terbatas hak untuk kebebasan bergerak di wilayah yang diduduki, telah diberikan perlindungan luas oleh Mahkamah Agung Israel. Perlindungan ini terbukti dalam garis panjang keputusan mengenai rute pagar keamanan Israel. Menyusul gelombang serangan teror, Israel mulai membangun pagar fisik untuk memisahkan wilayah Palestina dari Israel (Sourik, 1999: 86). 
Dalam banyak kasus, Mahkamah Agung telah memerintahkan rute pagar yang akan diubah untuk memastikan kebebasan bergerak, meskipun kesadaran bahwa Palestina memahami ini tidak akan membuat perjuangan mereka itu mudah.

\section{Proses Penyelesaian Apartheid Israel di Palestina}

Stop apartheid Israel adalah kampanye yang diselenggarakan oleh Skotlandia Kampanye Solidaritas Palestina dengan dukungan dari berbagai mitra dan pendukung termasuk serikat buruh, lingkungan dan aktivis akar rumput di Skotlandia dan Palestina. Wood Group adalah perusahaan minyak dan gas global dengan kantor pusat di Aberdeen. Perusahaan ini bekerja di 50 negara di seluruh dunia, termasuk Israel, dan menyatakan bahwa Wood Group melakukan bisnis di sejumlah bagian dunia di mana ada konflik menyedihkan yang menyebabkan kesulitan dan ketidakadilan. Sejalan dengan rencana yang tidak bertanggung jawab ini adalah kehormatan, Wood Group adalah membangun pembangkit listrik berbahan bakar gas di Israel yaitu pembangkit listrik yang akan mendorong lembaga-lembaga dan penegakan negara apartheid Israel (Setyawan, Ibid. Hal. 06). Tindakan yang Wood Group telah diambil dalam pembangunan pembangkit listrik ini akan langsung memicu kebijakan apartheid yang sedang berlangsung, infrastruktur dan lembaga negara Israel. Wood Group harus dibuat sadar keterlibatan dalam perampasan yang sedang berlangsung dan penindasan rakyat Palestina dan harus segera menghentikan menyediakan Israel dengan cara menerapkan apartheid. Wood Group harus segera menarik diri dari Israel dan menahan diri dari mencari kontrak masa depan dengan apartheid Israel.

Di Amerika kepemimpinan serikat buruh di AS secara umum enggan membela hak-hak Palestina. Kadang-kadang, telah secara terbuka bermusuhan dengan gerakan solidaritas Palestina. Segera setelah Richard Trumka terpilih sebagai presiden AFL-CIO pada tahun 2009, dia mengecam seruan boikot, divestasi dan sanksi (BDS) terhadap Israel. Seruan itu didukung oleh organisasi yang mewakili pekerja Palestina. Selain itu, AFL-CIO telah menjadi pembeli utama obligasi Israel yakni investasi bernilai \$ 5 miliar. Itu tampaknya tidak meyakinkan AFL-CIO sebagi federasi serikat buruh terbesar di AS ini berpihak pada pekerja Palestina. (Silver, 2017: Par 1-5). Serikat pekerja AS sebagai kunci keberhasilan aktivisme BDS, Jika para buruh terlibat dan mulai bertindak, serta menarik investasi dalam obligasi Israel.

Pada bulan November 2010 Wood Group menandatangani kontrak dengan Dorad Energy untuk membangun pembangkit listrik gas alam di Ashkelon, Israel. Kontrak ini bernilai sekitar $£ 563.000 .000$ dan pembangkit listrik 800 megawatt akan menghasilkan 
8\% listrik Israel dalam waktu dekat. Pembangkit listrik ini akan selesai pada 2013. Ladang gas baru telah ditemukan dalam wilayah Israel offshore dan Wood Group berniat untuk memperluas operasi mereka; Shlomo Cohen, manager Israel Grup tahun lalu menyatakan bahwa perusahaan menganggap proyek ini sebagai landasan untuk operasi ekstensif di Israel. Tindakan Wood Group akan langsung berkontribusi terhadap penaklukan yang sedang berlangsung dan perampasan rakyat Palestina. Telah ditetapkan bahwa pembangkit listrik akan memberikan energi untuk Kementerian Pertahanan Israel, Mekorot (perusahaan air nasional Israel), dan berbagai perusahaan swasta, termasuk Keter (Ibid.).

Setiap aktor pergerakan mempunyai peran untuk mendukung Palestina dengan memperluas gerakan ini dengan global yaitu mendorong melalui persatuan yang eksistensinya ada di setiap negara di dunia, seperti Dockers Swedia dan Norwegia mereka memamerkan aksi-aksi solidaritas dengan mendapat dukungann dari para guru untuk memboikot Israel dengan nilai-nilai Akademisi. Di setiap tempat kerja dan setiap industri, di setiap sekolah dan perguruan tinggi, pekerja dan pelajar harus mendapatkan persepsi yang sama dan membentuk kelompok agar terdorong solidaritas yang aktif dan dukungan aktif untuk memboikot, aktivis juga harus mengambil tindakan resmi demi gerakan yang lebih luas.

Seperti sebuah mercusuar, harapan untuk masa depan akan gerakan ini menjadi sorotan kemudain menciptakan sebuah gerakan kelas pekerja internasional yang bersifat global governance benar-benar ditunggu kehadirannya kepada warga dunia yang membutuhkannya. Ini adalah aset internasional yakni internasionalisme yang efektif kunci untuk membangun fightback yang sukses bukan hanya melawan penindasan masyarakat secara subjektif seperti di Palestina, tetapi menentang perang imperialis, kependudukan, dan upaya kapitalisi ke seluruh dunia (Hatuel et al. 2015. Par. 08). Dapat dikatakan pergerakan BDS ini adalah warna baru perjuangan dengan nafas internasionaslisme pergerakan yang kolektif.

Kemudian untuk penyelesain apartheid secara internal, pertanyaan yang kita hadapi bukan legalitas permukiman Israel di wilayah-wilayah, tetapi apakah kebijakan Israel di wilayah yang sama saja dengan apartheid. Oleh karena itu, terlepas dari status hukum mereka, praktik Israel mengenai permukiman bukanlah pelanggaran kejahatan apartheid. Para penulis jurnal menulis secara ekstensif menyatakan tentang fakta bahwa dalam beberapa kasus hukum yang berbeda berlaku untuk warga negara Israel dan Palestina di wilayah-wilayah. Dalam analisis mereka perbedaan ini mencerminkan 'alam rasial' Israel dan mendasari sistem dominasi (Dugard et al. 205-206). Perlu dicatat bahwa realitas 
pendudukan yang sedang berperang juga memiliki pengaruh atasi pelaksanaan hak vis-àvis warga Israel yang tinggal di wilayah-wilayah pendudukan. Tentu saja, ruang lingkup hak asasi manusia yang hidup di daerah Israel, dan tingkat perlindungan hak berbeda dari ruang lingkup hak asasi yang tinggal di Israel, serta tingkat perlindungan hak tersebut. Pada dasar diferensiasi ini terletak pada fakta bahwa daerah ini bukan bagian dari Negara Israel. Hukum Israel tidak berlaku di daerah. Dia yang tinggal di daerah hidup di bawah rezim penduduk yang berperang. Seperti rezim yang bersifat sementara.

Di lain sisi, Presiden Palestina yaitu Mahmoud Abbas, mengatakan bahwa PBB bertanggung jawab mengakhiri apartheid di Palestina yang disebabkan oleh Israel. Abbas menuturkan hal itu ketika ia memberikan pidatonya di Sidang Majelis Umum PBB Sebagaimana dikutip dari Times of Israel, Kamis (21/9/2017) Abbas menyatakan bahwa PBB seharusnya dapat mengakhiri kebijakan Israel yang bersifat menghasut ketegangan agama dan memicu konflik agama yang berdarah. "Kami dipercayakan dan Anda dipercayakan untuk mengakhiri apartheid di Palestina. Dapatkah dunia menerima rezim apartheid di abad ke-21?" pada Rabu 20 September 2017 waktu New York (Julio, 2017: Par 1-2). Tepat pada tahun yang sama Komite Sosial dan Ekonomi PBB untuk Asia Barat (ESCWA) mengeluarkan laporan resminya yang menandaskan bahwa negara Israel terbukti secara meyakinkan tanpa ragu bersalah melakukan kejahatan apartheid seperti yang dilakukan Afrika Selatan. Peran Quartet yakni Amerika Serikat, Rusia, PBB dan Uni Eropa, seharusnya menjadi aktor utama dalam membantu proses perdamaian Timur Tengah.

Pada tanggal 19 Juni 2018 (VDLC, 2018. http://vdlc.ca/boycott-divestment-andsanctions/. Diakses pada 08 September 2018) Mengadakan pertemuan reguler the Vancouver \& District Labour Council, para delegasi hadir mendukung gerkan boikot, divestasi, dan sanksi terhadap Israel sebagai tanggapan terhadap rakyat Palestina. VDLC beraanggapan bahwasanya; a) Pasal 49 Konvensi Jenewa ke-4 melarang kekuasaan pendudukan untuk memindahkan bagian-bagian dari penduduk sipilnya sendiri ke wilayah yang didudukinya, b). Pengadilan Internasional telah memutuskan bahwa pemukiman Israel di the Occupied Palestinian Territorie (OPT) melanggar hukum internasional, Resolusi PBB 194 menetapkan hak para pengungsi Palestina untuk kembali ke tanah dan properti mereka, c). Kanada dan negara-negara lain sebelumnya telah berhasil memastikan penghormatan terhadap hak asasi manusia melalui penggunaan sanksi ekonomi dan politik, termasuk dalam kasus Afrika Selatan, e). Dunia telah menyaksikan dengan ngeri ketika 
puluhan pemrotes Palestina yang tak bersenjata telah tewas, dan ratusan terluka, oleh pasukan militer Israel dalam beberapa pekan terakhir.

\section{KESIMPULAN}

Konflik di Palestina bukan konflik agama maupun rasial, tetapi konflik kepentingan penguasaan aset ekonomi-politik strategis oleh imperialis internasional melalui Zionis Israel sebagai peran utamanya, pembebasan hak asasi manusia yang bersifat nasional merupakan bentuk melawan imperialisme, perjuangan penghapusan kelas dengan cara menghancurkan kelas penindas. Posisi kelas mayoritas berkuasa demi kesejahteraan sosial, ekonomi dan politik dan tanpa adanya partisipatif hak asasi manusai bagi warga Palestina. Fenomena BDS Movements buruh menyikapi isu-isu penindasan ini khusunya anggota perserikatan menjadi tolak ukur tersendiri dalam kesatuan aksi yang bergaung di mana-mana di dunia ini. Sehingga bukan tidak mungkin sekecil apa pun yang mereka lakukan tidak menuai hasil, yang patut diapresiasi adalah persatuan kaum buruh membuka mata dunia bahwasanya ini adalah kesadaran kolektif demi tegaknya keadilan dari kejamnya penindasan yang terorganisir.

Persatuan gerakan buruh dunia harus menglobal meski keberadaan pergerakan ini berada di tengah-tengah konflik kepentingan di Palestina, membangun persamaan persepsi tentang boikot, sangsi dan pembasan secara global dalam melawan kolonialisme dan imperialisme demi hak-hak kemanusiaan yang bebas pada warga Palestina. Kedaulatan akan tanah tanah air mereka tidak hadir begitu saja, adanya gerakan bersifiat global governance merupakan usaha yang nyata dari masyarakat internasional barangkali tidak mudah dibentuk dan ditemukan hingga saat ini.

\section{DAFTAR PUSTAKA}

\section{Buku}

Amenta, Edwin, and Neal Caren, Elizabeth Chiarello, and Yang Su. 2010. "The Political Consequences of Social Movements", Annual Review of Sociology. 36: 287-307.

Documents and Teaching Material on Contemporary Practice in International Law (1999 Dugard and Reynolds,supra note 1, text to notes 205-206. Zaharan Yunis Muhammad Mara'abe, supra note 18, at para. 22. And Beit Sourik Village Council, supra note 29.). Geneva Convention IV, supra note 4, Arts 35, 48 Territory: A Reply to John Dugard and John Reynolds. England: Oxford University Press. 
Y. Sulaeman, Dina. 2009. Organisasi yang Pro Israel yang Mendukung UU EFCA; Obama Revealed: Realitas di Balik Pencitraan. Jakarat Selatan: Aliya Publishing

\section{Jurnal}

Bard, Mitchel G, (2008). "Israel Is Not An Apartheid State". Jewish Virtual Library. Archived from the original on 17 October 2015. Diakses pada 08 September 2018, jam 01.35 wib.

Farid, Hilman. 2014. Gerakan Sosial di Indonesia. Catatan Konferensi INFID 2014. (Global/Praxis_Gerakan_Sosial.pdf. Diakses pada 07 September 2018, jam 23.54 wib).

Hilmar Farid Perkumpulan Praxis

Cohen, E.R. 1985. Human Rights in the Israeli Occupied Territories 1967-1982. The Minister of Defence,.

Ekecutive Summary: Global Governnace. 2014. http://ppid.lan.go.id/wpcontent/uploads/2014/10/ES-Global-Governance-2010.pdf

Hatuel, Michal \& Radoshitzky. Israel and Apartheid in International Discourse. Strategic Assessment. Volume 18 No. 3 | October 2015

Yaffa Zilbershats. 2013. Apartheid, International Law, and the Occupied Palestinian Opp, Karl-Dieter. 2009. Theories of Political Protest and Social Movements. New York: Routledge.

\section{Internaet}

Apa itu Aparhteid Fakta Sejarah Infomasi Lainnya. Diakses pada 11 juni 2015, jam 11.00 am. (http://www.amazine.co/25039/apa-itu-apartheid-fakta-sejarah-informasi-lainnya/)

Dunia Peringati Minggu Apartheid Israel. Diakses pada 11 juni 2015, Jam20.00 pm. (http://www.muslimdaily.net/berita/internasional/dunia-peringati-minggu-apartheidisrael.html).

Julio, Emirald 2017. https://news.okezone.com/read/2017/09/21/18/1780150/abbas-pbbbertanggung-jawab-akhiri-apartheid-di-palestina. Diakses pada 08 Spetember 2018, jam 22.38 wib.

Seiawan, Rana. 2015. Serikat Buruh Terbesar Inggris untuk Israel Negara Apartheid. Diakses pada 11 juni 2015, Jam 20.00 pm. (http://mirajnews.com/id/internasional/eropa/serikat-buruh-terbesar-inggris-israelnegara-apartheid//). 
Setyawa, Doni. http://www.donisetyawan.com/politik-apartheid/ Diakses pada 08 September 2018, jam 01.18.

Tan, 2013. Politik Apartheid Musuh Mandela Sepanjang Hayat. Diakses pada 04 $\begin{array}{llll}\text { September } 2018, & \text { jam } & 21.44 & \text { pm). }\end{array}$ (https://www.liputan6.com/global/read/766421/politik-apartheid-musuh-mandelasepanjang-hayat).

(United Nation, 2002. http://legal.un.org/icc/statute/english/rome_statute(e).pdf. Diakses pada 08 September 2018

United Nation, 2016. http://www.unhcr.org/refworld/pdfid/3ae6b3c00.pdf Diakses pada 08 September 2018.

https://pengertianmenurutparaahli.org/pengertian-apartheid-dan-contohnya/ Diakses pada 08 September 2018, jam 00.16 wib.

VDLC, 2018. http://vdlc.ca/boycott-divestment-and-sanctions/. Diakses pada 08 September 2018, jam 23.20 wib)

Silver, Charlotte. 2017. https://electronicintifada.net/blogs/charlotte-silver/are-us-laborunions-finally-speaking-out-palestine. Diakses pada 08 September 2018, jam 23.36.

St John, Ronald Bruce, 2017.

https://web.archive.org/web/20100616015824/http://counterpunch.org/stjohn02022007. html. Diakses pada Diakses pada 08 September 2018, jam 00.16 wib.

The Human Sciences Research Council (HSRC), 2009. http://www.hsrc.ac.za/Document3227.phtml. Diakses pada 08 September 2018, jam 02.15 wib. 